\title{
How to Compete with Private Labels (PIs) as They Continue to Outperform National Brands
}

\author{
Artyom Kravchenko
}

\begin{abstract}
The significant growth of private label brands in many categories and marketplaces has reshaped the competitive landscape in the Consumer Packaged Goods (CPG) industry. Today, global CPG companies have to fight for market share not only against global players but also against local retailers that are capable of competing for customers by marketing their own brands. The purpose of this article is to (i) explain what private labels (PLs) are (ii) explain how PLs have gained ground over time and in different markets (iii) provide recommendations to global CPG companies on how to best compete with PLs.
\end{abstract}

Keywords: Consumer Goods, Private Labels, Strategy, Competition.

PLs, also known as store brands, are products that are produced by a contract or third-party manufacturer and sold under a retailer's brand name. Today, PL goods are offered in almost every consumer product category, including personal care, cosmetics, pharmacy, beverages, food, and many others. In fact, when introducing a private brand, retailers become accountable for the entire marketing mix of products. In other words, a store's management decides upon the PL's ingredients, packaging design, pricing strategy, promotion campaigns, and merchandising. Full control over the value chain and marketing mix allows a retailer to minimize costs and increase profitability. As a result, a solid profit generated from selling PLs facilitates the ability for retailers to decrease prices of PLs to drive sales volume while remaining profitable. Alternatively, retailers can reinvest profits into enhancing the products' quality or into promoting them more heavily within outlets. The bottom line is that with national brands, retailers have minimum impact on marketing strategy because they act as resellers of products. However, with PLs, retailers must control the entire process from production to merchandizing and make appropriate decisions within this process to market their own brands attractively alongside national ones. Hence, the first question is "How big are PLs?"

\section{PLs across the Globe}

PLs are on the rise across the globe, but to date the greatest market shares and increase of supply and variety are observed primarily in developed markets. The PL market developed in European countries for many years, with Spain, the UK, Germany, Austria, and Belgium having over one third of sales going to PL producers. A German grocer Lidl is known for its own products 
comprising $90 \%$ of its sales, which helped the company boost its supply chain considerably and start its market entry to the USA [1].

The global trend for PLs' increasing popularity and rising revenue share is expected to continue in most industries. For instance, the forecast of BusinessWire experts for the global houseware market in 2018-2022 is optimistic about PL houseware products, especially in the developing states [2]. In turn, Grand View Research issued a global outlook on the 2018-2025 PL market in the food and beverage industry, which also delineated firm growth trajectories for PL readyto-eat meals and healthy snacks. With this in mind, the GVR report forecasts a considerable share for PLs in the rising online food delivery system, expected to increase from \$7 billion in 2017 to $\$ 12$ billion in 2025 [2].

\section{U.S. Private Label Market Overview}

While European consumers have been reaping the benefit of PLs for many years already, U.S. consumers are now starting to catch up with the trend. Based on an IRI report, turnover in the CPG industry in the United States in 2017 increased by $0.5 \%$ and reached \$799B. At the same time, PLs outpaced national brands and have grown by $2.5 \%$ while national brands have shown only $0.1 \%$ increase in dollar sales. Moreover, in 2017 PLs outperformed national brands and the CPG industry in each department. A solid uplift in sales allowed PLs to gain dollar share in 2017, accounting for $14.8 \%$ vs. $14.5 \%$ in the previous year. As a result, total PL sales in the United States in 2017 were roughly \$120B (in 2013 PL sales were \$113B). Obviously, for the last few years retailers have done a great job in terms of expanding penetration of their own-brand portfolio, and within the next ten years, PLs are projected to take over $25 \%$ of market sales [3]. Table 1 demonstrates sales performance by department of the total CPG industry, national brands, and PLs in 2017 vs. 2016.

\section{Table 1}

Dollar Sales Change in the United States by Department in 2017* vs 2016

\begin{tabular}{|l|c|c|c|}
\cline { 2 - 4 } \multicolumn{1}{c|}{} & Total CPG & Total National Brands & Total Private Labels \\
\hline Beverage & $+\mathbf{0 . 4 \%}$ & $-\mathbf{0 . 1 \%}$ & $+6.3 \%$ \\
\hline Frozen & $+\mathbf{0 . 6 \%}$ & $-\mathbf{0 . 5 \%}$ & $+5.2 \%$ \\
\hline Beauty & $-\mathbf{0 . 6 \%}$ & $-\mathbf{0 . 9 \%}$ & $+3.2 \%$ \\
\hline Health & $+\mathbf{0 . 3 \%}$ & $\mathbf{- 0 . 3 \%}$ & $+2.5 \%$ \\
\hline Refrigerated & $+\mathbf{0 . 3 \%}$ & $\mathbf{- 0 . 4 \%}$ & $+2.0 \%$ \\
\hline
\end{tabular}




\begin{tabular}{|l|c|c|c|}
\hline General Merchandise & $+\mathbf{0 . 1 \%}$ & $\mathbf{- 0 . 4 \%}$ & $+\mathbf{2 . 0 \%}$ \\
\hline General Food & $+\mathbf{0 . 4 \%}$ & $+\mathbf{0 . 3 \%}$ & $+\mathbf{1 . 5 \%}$ \\
\hline Home Care & $+\mathbf{0 . 5 \%}$ & $+\mathbf{0 . 5 \%}$ & $+\mathbf{0 . 7 \%}$ \\
\hline
\end{tabular}

*Year-to-date ending 9/3/2017 versus same period 2016

Source: IRI (2017). Private Label 2017: The Evolution of Private Label in a Transforming Marketplace.

Despite the fact that national brands are still dominating the CPG industry, in some categories PLs are achieving leadership position, presenting major competitive challenges to top-tier manufacturer brands. For example, in the total paper category, with turnover of \$17B (in 2017), PLs' sales share reached $24 \%$ while in one particular subcategory they gained almost $50 \%$. In fact, in the toilet tissue subcategory, PLs attained fourth place based on sales share after P\&G, Kimberly Clark, and Georgia-Pacific; while with $30 \%$ of sales share in paper towels, store brands are second after the national leader-P\&G. Exhibit 1 shows the breakdown of sales in the leading PL category-paper products [3].

\section{Exhibit 1}

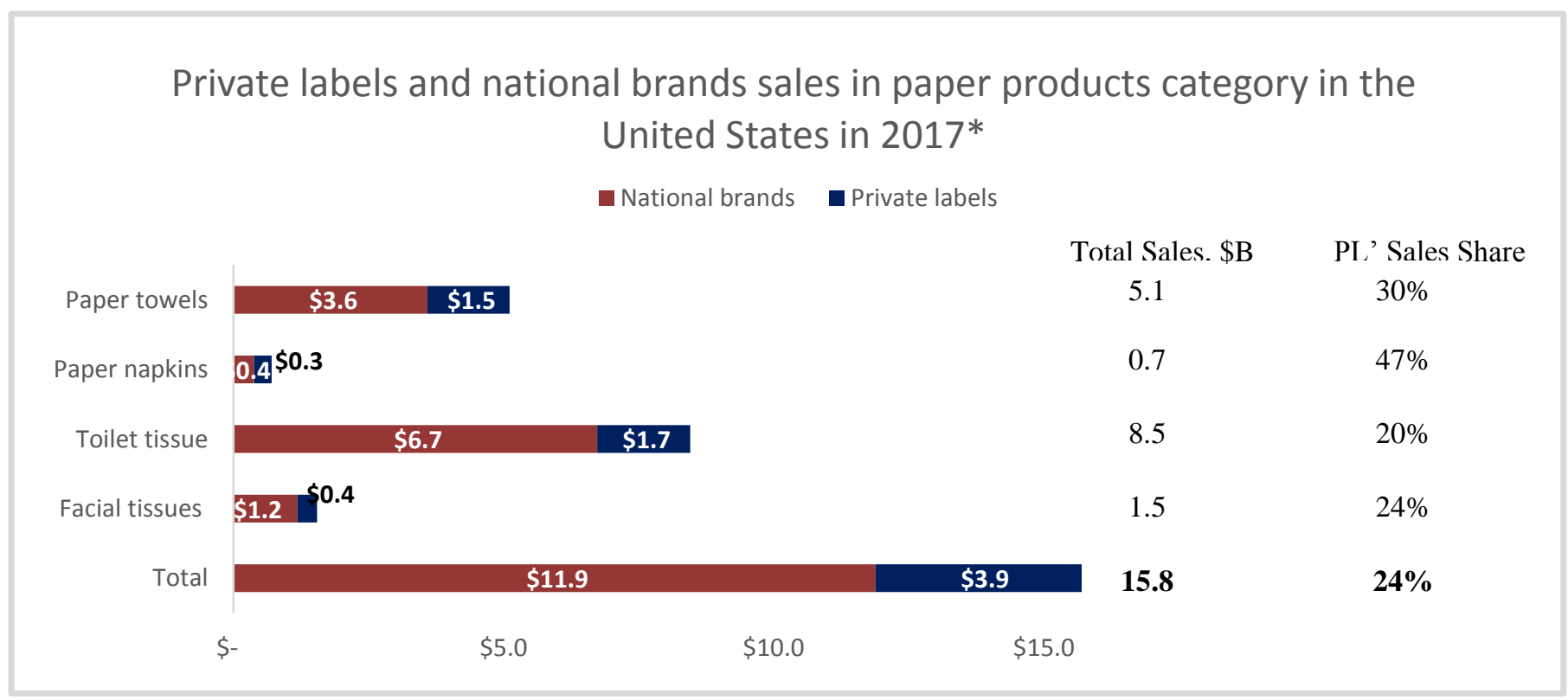

*52 weeks ended July 9, 2017

Source: IRI; Store Brands Magazine, October 2017, page 104

Nevertheless, PLs are gaining ground not only in physical stores but also in the e-commerce space. The tech giant Amazon has invested heavily in its AmazonBasics range, and currently is benefiting from penetrating its own brands into more and more categories. In 2009, Amazon launched 
its first PL, AmazonBasics, selling a full product line of electronic goods from disposable batteries to USB cords and laptop bags. Today, Amazon sells PL brands for everything from fashion to food, health supplements to household goods. Based on estimates by analysts at SunTrust, Amazon's PL sales were roughly at $\$ 7.5$ billion in 2018; by 2022, they are expected to hit $\$ 25$ billion [4]. Moreover, acquisition of Whole Foods (in 2017 Amazon bought Whole Foods for \$13.3 billion) allows Amazon to push PL goods even further by leveraging both channels - the e-commerce platform and physical stores. In fact, PLs seem to keep gaining more share in all retailing formats, but the question isWhy?

\section{Why Are PLs Thriving?}

A closer look at the penetration of PLs led me to figure out three key reasons contributing to the exponential growth of PLs.

\section{Attractive Price Points}

In developed markets PLs were traditionally aligned as cheaper alternatives to national, premium brands - this pricing strategy allowed store brands to gain market share, especially when consumers needed to make cost savings. Tamara Barnet, vice president of strategic insights at the Hartman Group, said: "During the recession, people were increasingly willing to trade down for a brand equivalent" [5]. She mentioned that the biggest jump of PLs' growth was in 2008 and since then it has been steady but decelerating, with incremental growth of 1-2\% annually. Two partners and senior directors of Bain \& Company, in their article issued in 2011, stated the following: "The global recession gave private labels an added boost, and in many categories the gains were sticky. Of 30 top US categories we analyzed recently, there was only one-yogurt - in which private labels lost share while brands grew in the years 2006 to 2010 " [6].

When an economy recovers from recession, however, consumers won't necessarily "uptrade" to return to national brands; and this pattern is a big driver of sustainable PL growth. Nielsen's report “The Rise and Rise Again of Private Label” emphasized: "When coming out of economic downturns,

consumers will maintain a more cautious approach with regard to household expenses, having developed a habit of seeking and expecting value for their money" [7].

Based on Nielsen's survey, 71\% of respondents from North America indicated that they purchase PLs to save money, which is close to the global average of $70 \%$. The highest rate is from 
the European Union- $81 \%$ of people chose PLs because of lower price points in comparison with multinational brands. In fact, store brands are most prevalent in European countries where their value share is about one third of the total retail industry turnover [7]. At the same time, $78 \%$ of respondents from North America said that it is important to get the best price on a product; the global average was $69 \%[7]$.

As a result, an attractive price tag is a major factor that stimulates shoppers to switch from manufacturer brands to PLs, especially when consumers are mindful of their spending. When retailers are able to offer good value for a reasonable price, they meet shoppers' most essential expectations, and that creates significant challenges for national companies.

\section{Product Differentiation}

Contemporary consumers have observed a shift of PLs from being only generic, low-end products to becoming more differentiated, more premium offerings with an individual appeal to customer needs and preferences (e.g., organic products, locally grown foods, healthy products, wellness products). This means that store brands have started to differentiate themselves in the marketplace and are able to fulfill needs unmet by major global brands. For example, Woolworths Macro Wholefoods is a retailer that understands the functional and emotional needs of shoppers in the world of healthy eating. Specifically, it differentiates itself by offering a huge range of healthy products at competitive price points [8]. Today, consumers are not only shopping but also eating differently - they demand more products that are natural, green, organic, and free of sugar, gluten, and antibiotics. Therefore, by providing the highest quality products in the healthy-eating segment, retailers consistently win the hearts and minds of their shoppers. For example, Aldi is expanding its fresh produce and organic assortment at ALDI.us/hellohealthy. Visitors find new offerings each week, including meal plans, recipes, videos, and tips on how to shop for a variety of eating styles, such as paleo, vegan, and plant-based. Aldi has partnered with food and lifestyle leaders Cookie and Kate, A Couple Cooks, The Healthy Apple, and My Heart Beets to curate recipes and meal plans and has enlisted an advisory council of registered dietitians who help shoppers find smart choices through products identified by the "Dietitian's Picks" emblem on their website [9].

In fact, wellness brands are the fastest growing segment in the private brands universe. Every retailer, from the most price-oriented to the most progressive, can differentiate with a wellness brand 
program suited to their customer segments and banner values. As a result, packaged goods face a challenge, because consumers' preferences have switched to fresh and healthy food.

\section{The Millennial Effect}

Compared to older generations, consumers under 35 differ in terms of shopping habits. They tend to try new brands, including PLs. According to McKinsey research, millennials are almost four times more likely than baby boomers to avoid buying products from "the big food companies" [10]. They also do a lot more research before buying, and they will buy brands that do more, provide more convenience and offer a variety of lifestyle options. Millennials are generally willing to pay for special things such as heath and fresh daily food - that is exactly where PLs are gaining market share. When looking at millennial shopping habits, we see that millennials are willing to spend on what matters to them, even though they seek value. Millennials in the United States are 9 percent poorer than Gen Xers were at the same age, so they have much less to spend and choose carefully what to buy and where to buy it. Therefore, in many categories they choose PLs instead of national brands [10].

\section{Final Thoughts: How Can Global Consumer Good Companies Respond to the PL Challenge?}

The threat to global consumer good producers emanating from the rapid PL market share growth is evident, so global giants need to take urgent measures to address the challenge and preserve their market shares. When developing a response, companies should keep in mind that the major reason for PLs' success is their unique appeal to consumers and a thorough understanding of demand. Thus, a response strategy should be developed based on market analysis and with specific consumer categories in mind.

The following trends rule consumer demand for PLs and may be adjusted by global giants:

$\checkmark$ Popular PLs may be roughly divided into two categories — affordable analogues of branded products and premium PLs with a strong differentiation (e.g., organic and natural products). Brands may also adjust their product offerings to the needs of these different consumer categories. 
$\checkmark$ Older consumers tend to be wealthier, while younger consumers spend less on their consumer product set. Global brands may adjust their product lines with a relevant appeal and pricing strategy for different age categories.

$\checkmark$ Online sales are also driving the market change, with fewer consumer products purchased in stores and a larger number of in-store sales going to on-the-go-meal solutions and convenience products. Brands may preserve their standing in the market if they take a more active role in the consumers' digital lives and offer products with distinct personal benefits.

$\checkmark$ Consumers strive to receive value for their money. They mostly stick with PLs because they find the same level of quality that a branded product has, but for a lower cost. If CPG producers innovate their products and offer higher quality, they may retain significant portions of customers unwilling to experiment with PLs and seeing the evident benefit of buying branded merchandise.

By taking these steps, CPG brands may regain a competitive advantage and preserve their market share in the USA and other countries. However, they need to realize that the market is evolving at an unprecedented scale, with numerous disruptive trends massively changing the market landscape. Hence, PLs are not the only challenge to which they must respond, and staying innovative, proactive, and not resting on their laurels is the most productive competition strategy even for well-established global brands.

\section{References}

1. Nathaniel Meyersohn. How a cheap, brutally efficient grocery chain is upending America's supermarkets. Published May 17, 2019. URL:

https://www.cnn.com/interactive/2019/05/business/aldi-walmart-low-food-prices/index.html [accessed 2019-05-26].

2. Laura Wood. Outlook on the Global Houseware Market Through 2018-2022. Published January 10, 2019. URL:

https://www.businesswire.com/news/home/20190110005334/en/Outlook-Global-

Houseware-Market-2018-2022---Conair) [accessed 2019-05-26]. 
3. IRI. Private Label 2017: The Evolution of Private Label in a Transforming Marketplace. November 2017 URL: http://mypbrand.com/2017/10/26/iri-private-label-2017-the-market-istransforming-quickly/ [accessed 2019-05-26].

4. Nathaniel Meyersohn. CNN Business. 2018.

5. Len Lewis. Private Label Continues to Gain Traction. 2017.

6. Kara Gruver. Matthew Meacham and Suzanne Tager. Deciding to fight or play in the private label arena. Bain\&Company, 2011.

7. Nielsen. The Rise and Rise Again of Private Label. 2018.

8. Surry Hills. Understanding Private Labels In Four Key Steps, B \& T Weekly. Jul 31, 2018.

9. Daymon Report. 2018.

10. McKinsey\&Company . Consumer Packaged Goods The new model for consumer goods., April 2018. 